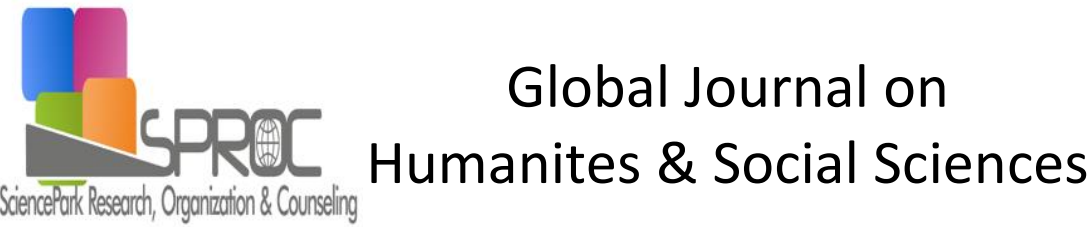

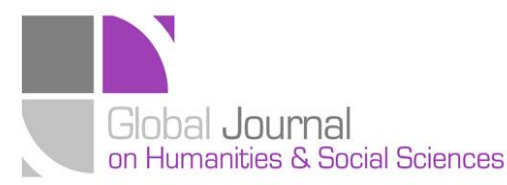

Issue 3 (2016) 557-563

Selected Paper of 4th World Conference on Design and Arts, (DAE-2015)

26-28 June 2015, St.Petersburg Christan University, St. Petersburg, Russia.

\section{Inventive traditionalism vs. considering tradition: The changing character of the city of Ankara}

\author{
Aktan Acar *, TOBB University of Economy and Technology Faculty of Fine Arts, Design \& Architecture, Sogutozu \\ Cad., Ankara, 06560, Turkey \\ Hakan Saglam, TOBB University of Economy and Technology Faculty of Fine Arts, Design \& Architecture, \\ Sogutozu Cad., Ankara, 06560, Turkey
}

\section{Suggested Citation:}

Acar, A., \& Saglam, H. (2016). Inventive traditionalism vs. considering tradition: The changing character of the city of Ankara, Global Journal on Humanites \& Social Sciences. [Online]. 03, pp 557-563. Available from: http://sproc.org/ojs/index.php/pntsbs

Received January 14, 2015; revised March 17, 2015; accepted May 06, 2015.

Selection and peer review under responsibility of Prof. Dr. Milan Matijevic.

(C)2016 SciencePark Research, Organization \& Counseling. All rights reserved.

\begin{abstract}
There are different forms of Traditionalism. The most common form is the one that promotes the "idea of having a tradition" itself as a discursive practice. The modus operandi of this form is the reproduction of the "images" considered as having symbolic meanings. Despite the consensus over their "symbolic communication", those images are deprived of their content that has been accumulated and articulated as a "tradition". The replacement of the accumulated knowledge, experience and consequently content with the "image" seems to initiate new traditions. It is possible to claim that it is a process of inventing those new traditions by means of "made-up" images of symbolic meanings.

Architect has a definitive position in this process. The profession proposes a dangerous mixture of being a technician lost its authority and identity within the over exhausting construction market, which multitudes the same building image, without content, on one side, and on the other, of having the ultimate responsibility of inventing and reproducing that "made-up images of traditionalism".

This study investigates the invention and reproduction of that made-up traditions through the transformation of urban morphology and texture of the city of Ankara with respect to the changing political and social atmosphere in Turkey.
\end{abstract}

Keywords: tradition, traditionalism, Ankara, city, politics

* ADDRESS FOR CORRESPONDENCE: Aktan Acar, TOBB University of Economy and Technology Faculty of Fine Arts, Design \& Architecture, Sogutozu Cad., Ankara, 06560, Turkey. E-mail address: aktanacar@gmail.com / Tel.: +90 5322020149 
Acar, A., \& Saglam, H. (2016). Inventive traditionalism vs. considering tradition: The changing character of the city of Ankara, Global Journal on Humanites \& Social Sciences. [Online]. 03, pp 557-563. Available from: http://sproc.org/ojs/index.php/pntsbs

The oversized cities in Turkey have been under criticism because of their way of growth and transformation. Ankara, the capital city, is having its share from those, especially heavier, critics, in relation to the striking amount of the constructions within the city. It is almost impossible to refer to any qualitative architectural success in Ankara. As a matter of fact, there is a number of actors responsible from that unhealthy development, including local and central authorities, market pressure, architects, citizens, etc. It is possible to examine the development and degradation of the architectural quality of Ankara with respect to any of these parts. This study, however, focuses on the "Architect" and its role in relation to the concept of "tradition".

Tradition is a dominating concept in all layers of social structure and public agenda. Most of the time, tradition is put forward as a trouble-shooter, explanation, or excuse for every contradictory issue of the society. Unfortunately, violence and killing against / of women have been the major topic of the news. Some "public figures", however, referred to the dressing or behaviours of women in public with respect to the "tradition". Those so called "public figures" have not only demonstrated a discriminative and offensive attitude, but also deprived of the content of the concept of tradition. It is fact that, through this kind of irresponsible way of using, tradition has been consumed in every field of social life. It has been losing its context, meaning and value. Its false implications and contentless form, nevertheless, have been invading and dominating the public realm.

The architectural practice, the realm of profession, is not free from this process. Tradition has been occupying a large volume among the client, architect, constructer and user. It has a growing impact, which has been expanding from the façades to the whole urban morphology. As matter of fact, when the real tradition is not "good enough" or silent, "new Traditions" are "invented". The positive denotations and connotations tradition, which is supposed to be the sum of accumulated experiences and knowledge body, are overwritten by "traditionalism" a blind and dangerous weapon.

Sociologically, tradition refers to customs, beliefs or behaviours, which have symbolic significance, of a group of people accumulated in time. It builds bonds among the member of the society and is transferred between the generations. In this respect, the transferred experience and knowledge body reinforce the surviving skills and relationships among the generations. Against this perspective promoting tradition as a living and changing body, there is another face of tradition that imply a solid and conservative character. It resists the change. In this case what we encounter is not the tradition itself, but rather "traditionalism". Traditionalism is referred in relation to "form" or appearance, which implies negative denotations and weakness (Mengusoglu, 2003).

Today, this kind of traditionalism is supersizing in almost every realm of our culture and social life, from our words and sentences to the urban-scapes. Its utmost concern is having "traditions" as the reason for its existence, legitimacy and identity. The executional forms of traditions, their symbolic meanings and importance as social values are the priorities of the traditionalism. In Turkey, it is possible to talk about a transformation from tradition to traditionalism as new "tradition" particularly in Architecture. This "traditionalist" perspective in Turkish architectural scene promotes pseudotraditional architectural forms as having cultural, national or religious values. In time, those invented values turn into taboos on which public criticism and dispute are limited, if not completely terminated.

Those pseudo-traditional forms of architecture in Turkey are represents, also, the political, economic, and cultural relations of the neoliberal capitalism and its institutions. In this respect, in order to exemplify the transformation of Turkish architectural atmosphere from a rich tradition of building and living experience to the formal representation of contentless invented traditions, which we call as traditionalism, it is compulsory to provide the brief of the circumstances. As a matter of fact, there are many invented tradition in Turkey. Each one is noteworthy to mention.

Professional organizations, academics and NGO's have a certain agreement on the critical topics of contemporary city, and consequently architecture: Economy is forming and transforming the architecture and city. As Harvey (Harvey, 2012) states "all the dynamics of urbanisation are 
Acar, A., \& Saglam, H. (2016). Inventive traditionalism vs. considering tradition: The changing character of the city of Ankara, Global Journal on Humanites \& Social Sciences. [Online]. 03, pp 557-563. Available from: http://sproc.org/ojs/index.php/pntsbs

determined by the neoliberal capitalism that is dominated by the big capital companies; we have to start to work in order to find out / invent another way of urbanisation." That "we" for sure contains designers, architects, planners, politicians, and sociologists who have any responsibility in shaping the cultural, economic, civil and physical structure of the urbanscape. Those dynamics and the forces of urban formation meet, clash and transform the public space. Kızılay Square, at the very political and social centre of the city of Ankara, is the battleground of those forces. It has survived from a number of tradition invention, particularly by the municipality. Unfortunately, some of the interventions have been survived, despite the loss of quality in public space and the identity of the city.

The existing square is only a roundabout without a real centre and public space. It was a part of an urban park which was surrounded by a memorial national monument on one side and a nice garden containing the small scale building of Kızlay, the Turkish Red Crescent, on the other. The decision of the local and central authorities for the demolition of the Red Crescent Building and the transformation of the garden into a plot for a shopping mall was the initiation of a new tradition in Ankara. Valuable but relatively small plots within the city has been forced to turn into the unearned income centre of capitalism. Those transformations have a significant impact on the social and cultural atmosphere of the city, compared to their physical area. An architectural competition was organized for the new building complex. One of the proposals that was eliminated in early stages of jury work was another urban park. Today, the square is a roundabout, and the garden is just the entrance platform of a shopping mall.

Another appearance of traditionalism is attempting to identify certain periods with political figures. The age of Pericles in ancient Greece, Augustus in Rome or Haussmann in Paris have been the role models for centuries. Although those examples mark the paradigm shifts in the history and initiated their own traditions, the traditionalist perspective tries to promote its own figure within its administration in order to justify its legacy and authority. The vision and courage of the political figures are of importance. But, the embodiment of that vision could only possible through the knowledge, skills and experience of a professional. That is why we do not recall the singular buildings during the Augustus period or Hitler's reign, but rather their perspectives. The role and importance of Palladio for the Renaissance, Mimar Sinan, who is identified with the classical period of Ottoman Empire, for the Suleyman the Magnificent, Speer for the Germania idea, or Wright for the American Dream can only be comprehended through that relationship.

One of the new Turkish tradition, within our traditionalism, is to try to identify the transformation of Ankara with certain local authorities with respect to their actual and practical interventions, instead of their visions or policies. The most famous, and unfortunate example is the current Mayor of the city of Ankara. Beside many other, two of his accomplishments are worthy to cite here: The ban of pedestrians from Kizılay Square and the placement of Transformer Robots and Dinosaurs on the roundabouts. In 2003, the Municipality in collaboration with the local authority responsible from the organization and coordination of traffic in Ankara decided to ban on-the-ground pedestrian circulation at the Kızlay square in order to let the vehicle traffic go faster without stopping at traffic lights. As a matter of fact this was another tradition invention attempt: The "automobile priority tradition" in Ankara. The pedestrians were forced to use subway passes, which did not have necessary amount of elevators and escalators. The public resistance with the help of the owners of the shops on the ground level, whose business was effected badly, back stepped the municipality, except the "no left turn" signs in any direction at the roundabout. Since then it is forbidden to turn left in Kızılay.

That "automobile and highway" traditionalism of Ankara has ended up with the highway tunnels, called BAT-ÇIK, which can be literally translated as "Dive and up". Almost every crossing points in Ankara has been by passed with tunnels. In fact, except the rush hours the traffic is pretty fast. But, every tunnel series has to finish with narrowing lanes and traffic lights, since it is impossible to dig everywhere in the city. Despite the long, wide and many tunnels, the traffic in Ankara is a mess. Unfortunately, this tradition has spread to the other cities in Turkey, like Bursa and Antalya. Although they are digging long and broad passes, which separate the cities into two, sooner or later they will 
Acar, A., \& Saglam, H. (2016). Inventive traditionalism vs. considering tradition: The changing character of the city of Ankara, Global Journal on Humanites \& Social Sciences. [Online]. 03, pp 557-563. Available from: http://sproc.org/ojs/index.php/pntsbs

realize that enlarging, extending, or diving the road shall not solve the problems raised by the massive use of automobiles in the cities.

The Transformers and dinosaurs have been the part of another tradition of placing giant statutes, especially fairy-tale characters in parks and clocks on the roundabouts in Ankara. The tradition of clock towers is of importance for the Modernity and industrialization. After nearly two hundred years, those clock towers seem anachronical, and awkward. Nowadays, the Mayor is marking the roundabouts with Tyrannosaurus Rex (T-Rex) models, which can move their bodies. The traditionalism, again, has produced a parody of tradition.

At the intersection point of the traditionalism of political forces and the capital accumulation pressure of the market emerges another "pseudo-tradition". Today, the Turkish economical system is heavily based on the building construction sector. As an issue of "representation", governments and municipalities take the advantage of issuing, initiating and advertising and finishing their constructional activities, such as highways, grand bridges connecting the two sides of Bosphorus, airports, hospitals, Palaces of Justice, school complexes, huge housing projects, so on so forth.

Beside the power of building the country, the formal language and visual appearance of those buildings claim a particular attention. It is a historical and architectural fact that "regimes" desire and produce a formal representation, as it could be seen in the Gothic Revival in France, governmental buildings of the United States of America, former USSR, nowadays in Kazakhstan, Turkmenistan, etc. The contemporary examples, mostly, utilizes the technological advancement in producing ultramodern buildings, rather than the nostalgic phantasms of a glorious pasts. In the case of Ankara, the image of the power has been produced by means of an imaginary composition of selected pieces from the past, eclectically. The most popular examples are the City Gates.

The City Gates have been promoted as the welcoming landmarks of the capital city. Twenty five years ago the former municipality had organized architectural competitions for those kind of landmarks in Ankara. The results were not implemented. Within the second decade of the twenty-first century, the Municipality initiated another process for the city entrances. As matter of fact, city entrances, too, belong to another chronological and ideological frame. They had cosmological, cosmographical, symbolical, and representational value for the fortressed cities of previous centuries. Today, the ways of communication and transportation demystify their attributed meaning and importance. Despite that, the City Gates of Ankara have been constructed, as an anachronical extension of past tradition. They can be described as Frankenstein-like combinations of building elements and symbols selected from the diverse sources of Anatolian civilizations, particularly Islamic tradition. Again, traditionalist perspective produces a corrupted image of tradition.

It is possible to encounter such corrupted images on the façades of Palaces of Justice and school buildings, too. Pseudo-Seljuk geometric compositions, pointed, or even horse shoe arches, which are almost completely alien to the architectural tradition of Anatolian civilizations, imitated blue and ceramic tiles are presented as the sign of respect and bond to the tradition. Without any consideration of the real content of those traditions, some images are invented and implemented. The end-product is nothing less than poor caricatures of Disneyland-kind of structures. This is another appearance of traditionalism.

The concern for the history and roots of local administration of the city of Ankara can be exemplified with the renamed streets and boulevards within last 20 years. Following the Modernisation project of the founding ideology of the republican period, the streets were labelled with numbers especially at the new city centre and surrounding neighbourhood. During the last twenty years the Municipality has renamed those streets. The newly given names indicates a certain consideration of identity in relation to the assumed geographical and historical roots: Kazakhstan Street (former Eight Street), Azerbaijan Street (former Third street), Tashkent Street (former first street).In fact, those numbered streets had been so internalized and become a part of the collective memory. They are still called their original numbers. Although the renaming has become a tradition, in 
Acar, A., \& Saglam, H. (2016). Inventive traditionalism vs. considering tradition: The changing character of the city of Ankara, Global Journal on Humanites \& Social Sciences. [Online]. 03, pp 557-563. Available from: http://sproc.org/ojs/index.php/pntsbs

which names of the current administrators are given to the boulevards and parks, the modern tradition's naming is prevailing. The attempt of erasing, reforming the collective - social memory of Ankara is being resisted by the daily practice of the citizens.

One of the rapidly developing tradition of the Turkish architectural and construction business scene is "urban transformation". To obscure the negative connotations, "Gentrification", which denotes displacement or deportation of former poorer and disadvantaged users, process has been promoted as the introduction of socio-cultural and economic quality and wealth, as ennobling. Despite the economic gain of transformation process, it is unfortunate that the flexibility, improvised and improved land use skills, respectful topographical placement, and neighbourhood relations of existing urban fabric, including slums, have been erased by the Gentrification. Turkey's Housing Development Administration (TOKi) is the governmental instrument of this process. TOKi and its type-project, uniform buildings belong to another invented tradition in Turkey. With their own words:

\section{"TOKI, with the models it has developed, functions as an umbrella rather than a competing body in the housing sector of Turkey in awareness of its responsibility as a guiding, supervising and educating organization and undertakes a significant role in production prioritizing the demands and solvency of the target masses in need."}

The mass houses of TOKI tradition are type-projects to be constructed with tunnel form system. The spatial and physical qualities of the all buildings are almost the same without any variation regarding to the climate, topography, social and cultural constraints. It produces exactly the same urban typology and morphology everywhere in the country. In fact it is not only a formal issue, but also about the spatial practice and economic conditions of the inhabitants. The daily practice of traditional settlements is heavily based on the interactions happened around common spaces, such as courtyards and fountains. The apartment-block type of living introduces much more enclosed daily life practice.

Beside the introverted character of these blocks, the expenses for maintenance of the common spaces brings extra financial load for the inhabitants. This leads another tradition in which the landlords sell their properties to move outer circles of the city where they can buy two or three properties with the money they make out their previous apartments. This circulation of money and people between the different areas of the city has been one of the basic movement type in Ankara.

Another significant gentrification related issue is the transformation of historical sites including living examples of traditional construction techniques. The last decade witnessed a major transformation in those areas. The increasing consideration about sustaining the social, cultural and financial accumulation of those areas is promising. The method of intervention, on the other hand, raises questions. The façades of those traditional Ankara Houses have been renewed by the help of local authorities. The most damaged ones have been demolished down and rebuilt from the very beginning. Unfortunately, the renovations of interiors were up to the owners, who mostly cannot afford the expenses. The result is fancy, newly coloured, decorated façades walls surrounding poor and desperate inner courtyards. This method has been administered in different parts of the old city. It seems to continue.

In fact, it is possible to mention many other similar cases from Ankara. It should be keep in mind that the actors and cases can vary but this kind of traditionalism is not an Ankara-specific situation. It is a common problem of societies whose dominating power is in search for justification by means of meaning and representation. The built environment is considered as a powerful way of producing this meaning and representation.

It is of significance to question the role and importance of the architect within this traditionalistic, tradition inventing context. The relationship between the power and the architect is a multi-layer one. The administrations' will to build is an important part of their existence and representation. To

\footnotetext{
* Quoted from the official web site of the administration. Retrieved from http://www.toki.gov.tr/en/index.html in 4.6.2015.
} 
incorporate their ideas they need professionals who has technical knowledge and the intellectual instruments of justification. Rem Koolhaas (Koolhaas, 1996) claims that architecture as a profession is a dangerous mixture of impotence and power. In our case, it is the no name-impotent- architect who executes the over-scale and countless projects of the ultimate power.

What is the role of Architectural education, which is supposed / claimed to concern the social issues and justice, housing problems, moral issues of the profession and public interests? What is the nature of the relationship between education and practice? Does education really prepare the students for the dangers of being mixture impotence and power? Do our considerations and discourses about the architecture, profession, and education help in explaining the prevailing situation of the built environment that has been formed by the traditionalistic attitudes of the power and its impotent professionals?

It is possible to add a number of other questions. The answer is, however, is hidden in the authority and licence in execution of the profession. In brief, architect has become a technician who is licenced to "form" the will of the power. The technical, economic and administrative responsibilities of the architect have been increasing since the professional organizations are insisting on the bureaucratic and professional recognition of the licence of the architect, whereas his/her authority has limited and demoted to the "form giving". The authority of architect as an intellectual or artist, however, is only relevant within the discipline, among other architects. There is an opposition to that idea which claims that architect has commission from public to determine the physical and aesthetic environment (Tanyeli, 2012). The praxis, however, tells a different story. Neither the public expectations, nor the will of the power seem to meet the architect's self-commissioned, mystified and over-rated role. On the contrary, the public is eager to consume the architectural production, which is reduced to the form, if not completely to the façade. The rapidly changing expectations of the public are corresponded by an architectural supply that has multi-identity, each of which is a fashion icon subjected to temporary interest and rapid consumption. This multi-identity, which is ready for multiplication and immediate consumption, however, can be described as a kind of "identity-lost" since there is no historical, social, cultural or geographical reference behind (Arslan, 2009).

For sure that dangerous cooperation of the power and architecture is not a Turkey-specific issue. The XXX-L extreme buildings of huge Chinese cities have initiated a new tradition. The architects, however, mostly from Europe and the United States. Ironically, some Chinese authorities recently called especially foreign architects for designing responsibly. The iconic buildings of famous continental architectural firms around the world have been trying to escape the "Cartesian rationalism and Newtonian Universalism" as a new tradition while getting out of former traditions. "In any case, it is obvious that all those iconic buildings and urban interventions are the consequences of that poisonous relationship between power and architecture. Although the direction and magnitude of the relation can vary, the architectural product always is deduced to an image for consumption.

In case of Ankara, since the direction of the relation is from power to the profession, the invented traditions are utilized to manipulate the public opinion. They are assumed as representing a historically and culturally legitimate authority respecting the past. They demonstrate the economic pote 
Acar, A., \& Saglam, H. (2016). Inventive traditionalism vs. considering tradition: The changing character of the city of Ankara, Global Journal on Humanites \& Social Sciences. [Online]. 03, pp 557-563. Available from: http://sproc.org/ojs/index.php/pntsbs

\section{References}

Mengusoglu, T. (2003). Felsefeye Giris. İstanbul: Remzi Kitabevi.

Harvey, D. (2012) Kapitalizmin Krizi ve Kentsel Mucadele. trans. Arif Sentek. Mimarlık, 367.

Koolhaas, R. (1996). Ogrencilerle Soylesiler. trans. Nazım Dikbas. İstanbul: Yem Yayınları.

Tanyeli, U. (2012). Mimarlıkta Degismekte Olan Ne? Biçim Bilgisinden Sureç Bilgisine. Arredamento Mimarlık, 09.

Arslan T., V. (2009). Yok Mekanlar ve Kimliksizlik: Alısveris Merkezleri Orneginde Yok-(çok)-Mekan Olgusu. Mimarlık. 347.

Received June 04, 2015 from: http://www.toki.gov.tr/en/index.html

Received June 09, 2015 from: http://www.architectmagazine.com/project-gallery/musee-des-confluences 